\title{
UNDERSTANDING VISITORS' MOTIVATIONS OF SHARING EXPERIENCES RELATED TO HUNGARIAN TOURISM EVENTS AND FESTIVALS
}

For Generation Z (born after 1995) tourism during the summer usually means visiting festivals (especially music festivals) seeking extraordinary experiences. For them the classic tourist attractions are not satisfying and interesting anymore. The aim of the paper was to examine the measurement methods for sharing experiences related to these festivals and tourist programmes, and understand how other tourists use these shared experiences during the information gathering phase. The methodology is based on literature review and quantitative primary research. A structured questionnaire was used for the quantitative research focusing on the motivations of sharing travel experience and sources of information gathering. The data were collected by means of an on line survey via LimeSurvey, and descriptive statistics was used to interpret the acquired data. As a result of the quantitative research, three different groups of Hungarian youngsters visiting local music festivals were formed. For them, sharing that experience means different things: some only create memories for themselves, some try to create valuable content that may help others, and some want to become a social media celebrity. They use social media and they also gather information in a different way. Knowing how these groups use social media to share experiences and to get information are key factors for marketing managers in order to use an efficient communication method with each group. It is also an important factor to understand the differences in people's motivations with the aim to create a well-planned marketing campaign.

Keywords: customer motivations, festival tourism, generation Z, social media, tourism experience

JEL Classification: M31, Z30, Z33

DOI: $10.15611 /$ aoe.2021.2.05

\section{INTRODUCTION}

The relation between festivals and tourism has a long history, but these events have never been so popular as in recent years. Visiting a music festival has become a must-do summer programme for Generations Y and Z. Such

\footnotetext{
* Department of Management and Business Economics, Budapest University of Technology and Economics (BME), Budapest, Hungary.
} 
events also have significant economic, cultural, and social value for many stakeholders of the destination. The experiences from the festivals are shared via social media during and after the event. All such feedback also provides information for future consumers.

Scientific papers usually deal with the analysing the tourist experience, and information gathering and sharing (see e.g. Campos et al., 2016; Choe et al., 2017; Coelho et al., 2018; Kang and Schuett, 2013), but there are fewer dealing with the same topics concerning festival tourism (see e.g. Mehmetoglu and Engen, 2011; Rivera et al., 2015; Semrad and Rivera, 2018).

The aim of the study is to show results of secondary and primary exploratory research related to sharing experiences of Hungarian festival tourism. The article shows both the motivation side of sharing experiences (during and after the trip) and also information gathering based on the shared experiences by others (before the trip and the decision to go there).As part of the exploratory research about festivals, based on the secondary research and literature review, the primary research was conducted to examine the motivation of sharing their experiences, and the factors of the information gathering process with the use of a quantitative questionnaire. This exploratory research can help to understand motivations and user behaviour patterns, and form hypotheses for further research.

\section{LITERATURE REVIEW}

\subsection{Defining events and festivals}

Events such as community programs have taken place at all stages of our history. Their goals are enhancing the mood of the people, providing them with new experiences, and letting them escape from their everyday life (Harsányi, 2013, pp. 300-301). One of the most important factors in tourism is the change of the environment that consumers are used to. Akgunduz and Coşar (2018) and Getz (2008) provide several definitions of events in tourism. Morgan (2008) also suggested almost similar definitions for events. The most important factors are to come up with a good idea, and create cultural basis; these are carefully designed experiences where people get together for a particular duration, and its concept. Events and festivals provide a tourist experience also for the local population, to enjoy it without leaving their home town. To define a tourist event, the most important factors are: pre-organized, temporary availability, its purpose, specific aim and place (Fazekas-Harsányi, 2011). 
Today's tourists are not bound by the existing infrastructure, features and attractions of a city, but rather by the experience. Special events and the related experiences today have a decisive influence on tourism marketing. Husz (2012) also emphasized that tourist attractions become more attractive if one associates certain events and experiences with them.

One of the solutions for attracting tourists is to organize events, which in many cases involves many and various local stakeholders. One can see that not only residents of other cities are worth of communicating with, but these events also provide a tourist attraction for the locals, so the effect is always double, because when the local inhabitants experience good feelings, tourists are also willing to enjoy themselves. Soldić Frleta (2018) described the significant change of importance and performance of cultural events and entertainment during a holiday trip, studying period between 2014 and 2016.

Festival tourism is an increasingly popular feature of event tourism. Festivals can be interpreted as a series of events (Kundi, 2011), and festival tourism takes place when people travel to a destination at the time of the festival to visit at least some of the events (O'Sullivan and Jackson, 2002). Because of their complexity, festivals "combine different cultures and genres, from which the audience and the cultural-artistic life can both win" (Hunyadi et al., 2006, p. 25). Thus, the visitor will receive a concentrated package of individual programmes in a short period of time to help maximize their usefulness.

Festivals - especially music festivals - for younger generations can also function as the primary tourist attraction. In the case of older generations, regarding also festivals connected with food, tradition and arts, visitors do not go to the destination especially because of the festival, thus the festival becomes a secondary attraction. This type of event encourages tourists to consume more and more, stay longer at the destination, therefore "strengthen the attractiveness of tourist destinations" (Husz, 2012, p. 94.). According to Hunyadi et al. (2006, p. 31) basically, if the festival was their goal for travelling, more is going to be spent on meals, tickets and other programmes.

\subsection{Music festivals in Hungary}

The most important and most popular music festivals in Hungary are the Sziget Festival, VOLT, Balaton Sound, EFOTT and Strand. The most important cultural festival is Múvészetek völgye. The questionnaire used the primary research focused on the visitors of these festivals.

There are several literature sources which analysed the habits of Hungarian youngsters connected with their music festival attendance, but most of these 
sources have lost their usefulness (Kovács, 2009a; Kovács, 2009b; Sija and Schauermann, 2009; Deli-Gray, 2010; Rátz, 2012); some of these sources can be used to define the target population of a questionnaire about music festivals in Hungary.

On such basis it can be summarized that one-third of the Hungarian audience of Sziget Festival was under 20, around 30\% - 20-24 years old, and fewer than $20 \%$ of the visitors are aged 29 and over. In the case of foreign tourists, the proportion of those over 29 was even lower (15\%), although visitors under 20 make up 20\% also (Kovács, 2009a); 60\% of Hungarian visitors come from the capital and another $13.4 \%$ from Pest County; $55.6 \%$ of the visitors are full-time students, and every second visitor attended university or college (Kovács, 2009a).

According to Sija and Schauermann's (2009) survey of 15 to 25-year-olds: $56 \%$ had already attended a festival during the summer, while $22 \%$ of young people visit festivals on a regular basis, which means that they go to an event every summer.

\subsection{Social media, smartphones and tourism}

Information technologies have changed the way tourists gather information and plan their travelling. Similarly to the IT sector (Kovács and Petruska, 2019), tourist companies had to change their marketing tools to adapt the changes in innovation activities based on Internet technology, and build welldeveloped information systems. Elements of Web 2.0, the social media and websites based on user-generated content (Facebook, Instagram, YouTube, TripAdvisor, Wikipedia) enable tourists to communicate with each other and create a more informal and intimate relationships with destinations, businesses, and other international travellers.

Minazzi (2015), focusing on tourism marketing, classified social media into five categories which are close to those suggested by Kaplan and Haenlein (2010):

- collaborative projects for sharing general knowledge and editing each other's content (e.g. Wikipedia)

- virtual communities for sharing information, content and opinions (reviews) about a specific topic (like TripAdvisor or personal blogs concerning travelling)

- content communities for sharing media contents like texts, videos, photos (e.g. YouTube, Flickr, Pinterest, Instagram)

- social network sites (SNSs) for creating profiles with personal information sharing them with a network of friends and using instant messaging (e.g. Facebook) 
- virtual games/social worlds platforms (e.g. online games on smartphones, tablets, websites).

Choe et al. (2017) suggested in their primary research the use of six categories of social media to understand their usage during the different phases (travel reviews, social networks, photo and video sharing, micro-blogs, personal blogs, online communities / forums based on special interests).

Mobile technology allows visitors to get real-time information before, during and after the trip. The users are not just information seekers but also creators of information - which is a significant shift in their roles (Tussyadiah, 2015; Wang et al., 2014). Choe et al. (2017) indicated that tourists can use different social media elements in the phases of their trip, and can use the same element also in different phases of the trip for different reasons. Taneja et al. (2012) also suggested that users have different media usage strategies because for several reasons, such as diverse information needs or different attitudes, and their ability to use media channels. Xiang et al. (2017) also showed the different functionalities and roles of travel review sites, as these can be part of different media usage strategies.

Although there are several user strategies for using social media, the so-called user-generated content, or (in the case of tourism) the traveller-generated contents (TGCs) are becoming more and more important as a vital source for travel decision-making and also sharing experience (Marine-Roig, 2019). According to that study, analyzing TGCs is a vital information source for destinations, to understand the brand image created by the users that can influence potential visitors to the place. There are several articles that use web-scrapers and datamining for traveller-generated contents (e.g. texts, reviews, and photos) to define brand images (see e.g. Nowacki and Niezgoda, 2019; Marine-Roig and Anton Clavé, 2015; Kladou and Mavragani, 2015; Deng et al., 2019).

There are also numerous studies and articles about tourists' behaviour on social media, and others showing the results of using social media during all phases of the travelling process (Gretzel, Yoo, 2008; Xiang, Gretzel, 2010; Kang, Schuett, 2013; Wang et al., 2014; Tussyadiah, 2015; Nemec Rudež, Vodeb, 2015; Choe et al., 2017; Sedera et al., 2017; Zavodna, Zavodny Pospisil, 2018). Choe et al. (2017) stated that the usage of social media in the pre, during and post-trip phases differ significantly based on the timing of the trip, the information needs, the context, the trip type and access to the Internet. Thus it is clear that although many studies deal with the classic tourist experience and social media, the usage of these websites and apps should be quite different for festival tourism which has its special timing, is based on special needs and motivates mostly the younger generations to travel and enjoy experiences in other destinations. 


\subsection{Motivations for sharing experience and the consumer decision process of tourism}

For understanding the process of tourism, the consumer decision-making process proposed by Keller and Kotler (2016) and the three-part travel process (pre, during, and post-trip), proposed by e.g. Choe et al., 2017) were brought together in this study. During the pre-trip phase, problem recognition, information gathering, alternative evaluation and decisions occur regarding the destination (or the festival itself). After the decision, further information gathering takes place in terms of details of the trip. During the trip, further problem recognition is carried out and further decision-making processes are implemented. The fifth phase, the post-purchase effect suggested by Keller and Kotler (2016), and its post-purchase dissonance can also emerge during the three phases of the travel process.

Kang and Schuett (2013) suggested that user-generated travel information shared on social media is often considered as more reliable information than that provided by the organizations and private sector members. Wang and Fesenmaier (2004) showed that participation in an online travel community plays an important role in their social (communication, relationship, involvement, trust), functional (information, efficiency, convenience) and hedonic (entertainment, enjoyment, fun, amusement) needs. Deng et al. (2019) also found that users with different cultural background share different types of content and emotions on social media. Munar and Jacobsen (2014) pointed out that usually users have altruistic motivations too, like helping others, or wanting to prevent people from using bad products. For sharing travel experience, Kang and Schuett (2013) found a moderately positive relation between using social media in travel planning and sharing the actual experience of a trip, and the use of social media and sharing one's experience on them. Kim and Fesenmaier (2016) investigated the effect of sharing a negative or positive experience in social media at the post-trip phase. They also confirmed the effect of sharing on post-purchase dissonance.

Focusing on the post-trip phase and sharing of experience, Rivera and Semrad (2018) pointed out that general satisfaction has a strong impact on how memorable the event was, and how much the visitor will remember the festival afterwards. Their research also showed that a moderately strong relation can be found between the appearance of electronic Word-Of-Mouth and the memorable experience. Rivera et al. (2015) examined post-travel consumer behaviour instead of eWOM, and they were able to show a strong link between the memorable experience and the subsequent behaviour.

This experience sharing is closely related to the Zero Moment of Truth model by Lecinski (2011), which interprets the consumer purchasing-decision 
process as a feedback loop. An important moment after experiencing the product is the sharing of consumer experiences, which helps provide the feedback and prepare the decision process for later consumers. However, this feedback part of the process is much less frequent according to the model, than gaining the experience of the product. Munar and Jacobsen (2014) divided the motivations for sharing online tourism experiences into selfcentred and community-related ones. They also showed that the most common role in online communities are the 'lurkers', who read but never post.

Therefore, it is necessary to encourage consumers to share their experiences with the tour operators. To achieve this, marketers should understand the social media usage of the information seeking phase and the experience sharing.

According to Süli and Martyin's (2017) questionnaire research, young people used Instagram, Facebook and Snapchat at the festival in Szeged (SZIN) and the transborder Serbian (Green Future) festival. According to their results, festival attendees will not only share their experiences, but will also seek out the experiences of others through not just Facebook and Instagram but also YouTube and Google search. Video searches, especially the so-called 'aftermovies', appear most often in searches.

Xiang et al. (2015) presented the results of surveys from six consecutive years (2007 to 2012). They emphasised the importance of the Internet, wordof-mouth and the previous experiences in the decision process, which remained the same and showed significant increases for social network sites $(13 \%$ during the six years) and photo and video sharing sites (8\% during the same period of time). For online travel planning activities, according to the results the most significant increase was watching videos (15\%), "looking at comments/materials posted by travellers" $(13.4 \%)$, and reading travel-related blogs $(8.2 \%)$. These actions are all usually connected to social media and sharing experience. On the other hand, Munar and Jacobsen (2013) investigated how users of the different social media use them and how reliable they feel these types of media are. They found that virtual communities like TripAdvisor and information from acquaintances on social network sites, are perceived as more reliable than groups on social networks, tourist blogs and micro-blogs.

Kim et al. (2015) analysed these factors using the perspective of different generations. They stated that it is more important for Generation Y than for older generations to watch videos or read travel-related blogs. However, "looking at comments/materials travellers have posted" has almost the same importance for all of the generations. Personal blogs, consumer-generated content sites, photo and video sharing and social network sites are much more significant channels for the younger generations. Although they only conducted research for Generation Y and older ones, based on the trends for Generation $\mathrm{Z}$, these social media sites should be more important and have a more significant role in travel planning and decision-making. 


\section{METHODOLOGY AND RESEARCH QUESTIONS}

\subsection{Research questions and hypothesis}

The results of earlier research showed that there is a stronger relation between the overall experience of a festival and the five factors of experience that Semrad and Rivera (2018) suggested. Conneverall experience, longlasting positive memories have a strongly positive effected to the oct on loyalty, but only a somewhat moderate effect was discovered in regard of sharing their memories (also found by Rivera et al., 2015). Based on the ZMOT model by Lecinski (2011), the lack of sharing their experience is an important problem of the feedback loop, because in the decision-making phase of the journey, consumers usually use these previously shared memories to form their own attitudes and preferences. In the primary research the authors tried to understand this loop and the motivations of sharing experiences in a more detailed way. To create hypotheses, the ZMOT loop was divided into two main phases: 1) information sharing and 2) information searching and gathering, and based on these two research questions and four hypotheses were formed.

RQ1: What are the most important motivation factors in sharing experience, are they almost the same for everyone?

To answer research question 1, the different motivations in primary and secondary research were collected into statements. Following Taneja et al. (2012) and Choe et al. (2017), there should be different strategies of using social media to share experiences, and they have different motivations. Depending on the strategies it is also possible to form groups of users. The hypotheses for this question are:

H1: There are significant differences in motivation factors for the visitors, so different groups can be formed based on the motivations.

H2: Showing our happiness through our experiences as a self-expression is the most important factor for the majority.

The other research question was formed to understand the information gathering process. For this part of the study, the study used mainly the research by Xiang et al. (2015).

RQ2: How important are the social media elements for information gathering in the case of festival tourism?

For this question two other hypotheses were formed. Xiang et al. ( 2015) and Kimet al. (2015) suggested that for Generation Z, social media are becoming more and more important. The patterns of social media usage discovered by Choe et al. (2017) also include in several cases the photo and 
video sharing and social networking apps. Based on H1 for RQ1, another hypothesis was formed to understand the differences among the groups by motivations - if there are any.

H3: Social media elements have an important role in gathering information for festival tourism, and its role is getting more and more significant.

H4: Social media elements have different effects on information gathering for different groups of people based on the motivations to share experience (if these groups exist).

\subsection{Methodology}

Based on the results of the previous research by the authors, a questionnaire survey was designed to collect information about the factors of experience for Generation $\mathrm{Z}$ regarding tourism generally, festival tourism and five specific festivals in Hungary (VOLT, Balaton Sound, EFOTT, the Sziget Festival and Strand). The survey also included questions about the motivations of sharing their experiences (16 statements) and how they searched for information online before visiting a festival or going on a tourist trip (based on Xiang et al., 2015 and Minazzi, 2105). This questionnaire was part of an exploratory research on Hungarian festivals.

The questionnaire was conducted three times: in the autumn of 2016, 2017 and 2018. The target population was members of Generation Z (aged between 18 and 25) in Hungary who attended at least one music festival in the same year. This filter helped to collect relevant answers concerning the mentioned years' festival experiences, and also created the opportunity to investigate some trends and tendencies during the years (cf. Xiang et al., 2015). As shown in Section 2.2, university students (aged 20-29) from the capital city of Budapest or its surroundings are an important and significant part of the festival visitors. To reach them, students from several universities in the capital and other major cities of Hungary were asked to fill in the questionnaire (the same pattern as used by Süli and Martyin, 2017). This provided a convenient sampling method (combined with snowball sampling), which according to Malhotra and Birks (2007) and Malhotra et al. (2017) can be an efficient, the least expensive and time-consuming method, acceptable in exploratory research and used for pre-testing questionnaires and pilot studies, with the limitations mentioned in Section 5. The goal was also to validate the hypotheses that we can use later on a broader sample with the probability sampling method. To employ this convenient sampling method, the authors followed studies by Mitev et al. (2017), Kelemen-Erdős and Mitev (2020) and Zavodna and Zavodny Pospisil (2018). 
An online questionnaire software (LimeSurvey 2.64.7) was used to collect the answers into a database. This online software provides a wide variety of question types and also has an advanced system of creating conditions. Based on the festival attendance, the users had to answer semantic scale questions about the experience, loyalty, long-lasting memories and sharing their experiences for the specific music festivals. For measuring motivations the semantic scale was also used. The statistical evaluation was made with IBM SPSS Statistics V26 based on the suggestions for statistical basis by Sajtos and Mitev (2007) and Hair et al. (2014).

In 2016, during the sampling period, 738 valid answers were received and analysed, in $2017-572$ and in $2018-844$.

\section{RESULTS}

To answer the two questions (RQ1 and RQ2) and make decisions about the hypotheses for the previously mentioned sample, and to suggest the hypotheses for use in further research, the results are divided into two parts. The basic demographics of the valid answers for the three years are shown in Table 1.

Table 1

Demographic data for the three years

\begin{tabular}{|c|c|c|c|}
\hline Year & 2016 & 2017 & 2018 \\
\hline \multicolumn{4}{|c|}{ Sex } \\
\hline Male & $45.6 \%$ & $50.9 \%$ & $68.7 \%$ \\
\hline Female & $54.4 \%$ & $49.1 \%$ & $31.3 \%$ \\
\hline \multicolumn{4}{|c|}{ Age } \\
\hline 18 & $17.4 \%$ & $11.0 \%$ & $7.5 \%$ \\
\hline 19 & $36.8 \%$ & $33.6 \%$ & $21.0 \%$ \\
\hline 20 & $24.0 \%$ & $35.0 \%$ & $30.0 \%$ \\
\hline 21 & $10.0 \%$ & $8.9 \%$ & $24.8 \%$ \\
\hline 22 & $6.1 \%$ & $6.8 \%$ & $10.8 \%$ \\
\hline 23 & $3.0 \%$ & $2.8 \%$ & $3.5 \%$ \\
\hline 24 & $1.8 \%$ & $1.4 \%$ & $1.3 \%$ \\
\hline 25 & $1.0 \%$ & $0.5 \%$ & $1.1 \%$ \\
\hline \multicolumn{4}{|c|}{ Residency } \\
\hline Capital city & $48.3 \%$ & $47.7 \%$ & $43.5 \%$ \\
\hline City & $16.2 \%$ & $12.9 \%$ & $14.6 \%$ \\
\hline Town & $26.5 \%$ & $28.1 \%$ & $28.6 \%$ \\
\hline Village & $9.0 \%$ & $10.5 \%$ & $13.3 \%$ \\
\hline
\end{tabular}

Source: own research. 
This means that as the hypotheses were formed regarding visitors of the festivals, the authors only included respondents who had visited at least one festival in the same year. Although the distribution of the age was not even because of the small range of the years for the exploratory research, this distribution was accepted.

\subsection{Motivations for sharing experiences online}

To answer Research Question 1 (RQ1) in the questionnaire of 2016, 14 statements were created to understand the motivations of sharing experience online. In 2017 and 2018, two more statements were added to the list. Table 2 shows all the 16 statements and the codes that were used later in the figures and tables.

Table 2

Statements for research on motivations

\begin{tabular}{l|l}
\hline \multicolumn{1}{c}{ Code } & \multicolumn{1}{c}{ Motivation statement } \\
\hline MOTIV_01 & To show my friends and acquaintances how much I enjoy the festival \\
\hline MOTIV_02 & To show my friends that I am at the festival \\
\hline MOTIV_03 & To show others how great this party is \\
\hline MOTIV_04 & To show the world that I'm a real party-goer \\
\hline MOTIV_05 & I want others to see my perfect photos \\
\hline MOTIV_06 & To persuade my friends and acquaintances to go to the festival, too \\
\hline MOTIV_07 & To motivate others to share their own festival experiences \\
\hline MOTIV_08 & Make a memory of the festival for myself, which will help to remember things \\
\hline MOTIV_09 & Collect more likes \\
\hline MOTIV_10 & Not to miss out because my friends post photos too \\
\hline MOTIV_11 & What we do not post on the Internet, it is as if it had never happened \\
\hline MOTIV_12 & Make people envious that I'm at the festival \\
\hline MOTIV_13 & Reading the comments for the post is more fun \\
\hline MOTIV_14 & I would like to participate in the game, a riffle with the post, with a photo \\
\hline MOTIV_15 & $\begin{array}{l}\text { By presenting negative experiences, I want to help others make the right } \\
\text { choices }\end{array}$ \\
\hline MOTIV_16 & I'm just sharing a positive experience for others to see how good my life is \\
\hline
\end{tabular}

Source: authors' design.

Figure 1 shows the trends of the three years in motivations, and highlights the most important ones. Each statement was measured with the semantic scale of 1 to 7, where 1 was "totally not agree with the statement", and 7 was "totally agree with the statement". It can be seen that the motivation factors 
with the highest values for sharing experiences lost their importance during the course of these three years. Despite this trend, the aim to create memories for themselves to watch later and to remember the good experiences, were still important. This fact is also a contradiction: users share their experiences online for themselves and not for the others.

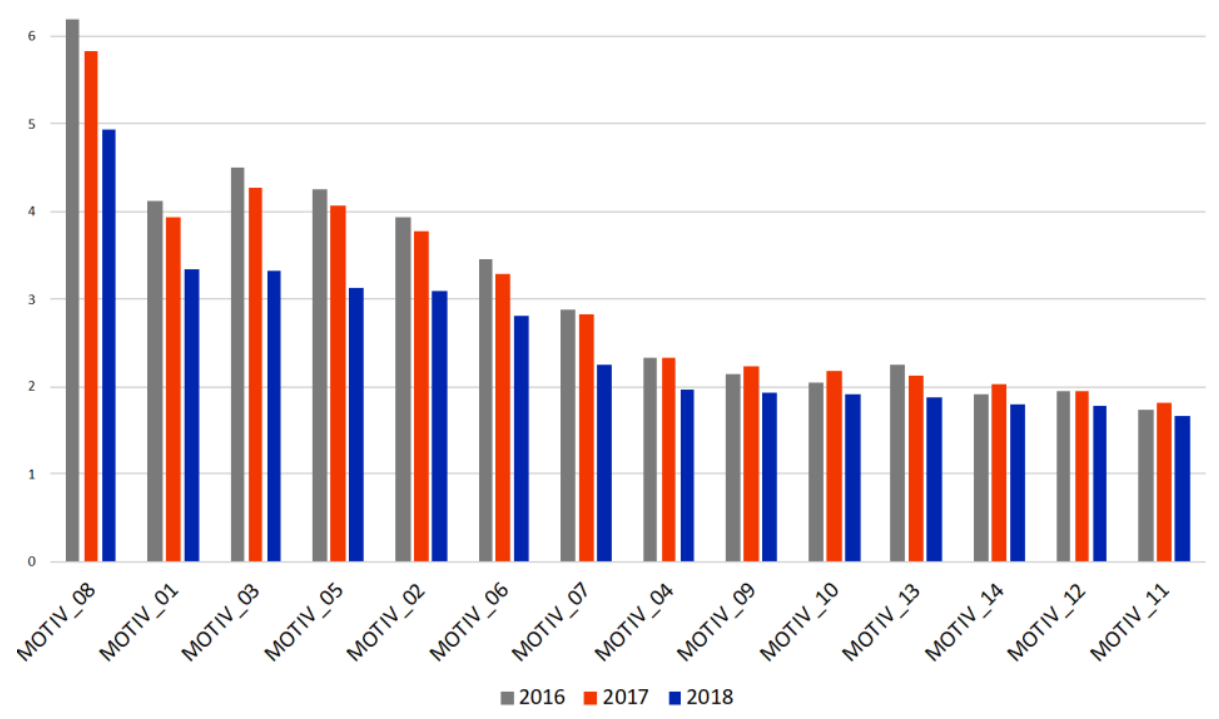

Fig. 1. Average values for motivations in sharing experiences during the three years

Source: own research.

Based on the results of the 16 statements in 2017 and 2018, the principal factor analysis was conducted. According to the scree plot and the variance explained, it was recommended to create four factors. VARIMAX rotation was used to help with interpreting the factors, and these four factors explained $67.65 \%$ of the variance. Table 3 shows the rotation matrix of the variables. Reliability was measured with Cronbach's alpha (CR), which indicates a higher reliability for all the construct. Table 3 shows that for three factors, Cronbach's alpha was more than 0.7 , and the last one was slightly lower than 0.7 (the KMO value was 0.920, Barlett's test of sphericity $=663.994, \mathrm{p}=<.001$, overall mean $=2.479, \mathrm{CR}=0.902$ ).

Motivations belonging to the first factor are focused on self-expression. These statements suggest that the user is rather extrovert and likes to show others how happy he or she is, trying to show only the good things to mislead 
Table 3

Factor loadings with VARIMAX rotation

\begin{tabular}{|c|c|c|c|c|}
\hline & $\begin{array}{l}\text { Self-expression } \\
\text { on social media }\end{array}$ & $\begin{array}{c}\text { Real experience } \\
\text { for myself } \\
\text { and others }\end{array}$ & $\begin{array}{c}\text { To influence } \\
\text { others }\end{array}$ & $\begin{array}{l}\text { Investment } \\
\text { for the future }\end{array}$ \\
\hline$\%$ of variation & $26.2 \%$ & $19.37 \%$ & $11.22 \%$ & $10.87 \%$ \\
\hline Eigenvalue & 4.192 & 3.099 & 1.795 & 1.739 \\
\hline Mean & 1.914 & 3.565 & 2.537 & 1.760 \\
\hline $\mathrm{CR}$ & 0.887 & 0.853 & 0.775 & 0.669 \\
\hline MOTIV_10 & 0.807 & & & \\
\hline MOTIV_12 & 0.800 & & & \\
\hline MOTIV_11 & 0.783 & & & \\
\hline MOTIV_09 & 0.776 & & & \\
\hline MOTIV_04 & 0.664 & & & \\
\hline MOTIV_16 & 0.650 & & & \\
\hline MOTIV_08 & & 0.782 & & \\
\hline MOTIV_01 & & 0.753 & & \\
\hline MOTIV_03 & & 0.714 & & \\
\hline MOTIV_05 & & 0.706 & & \\
\hline MOTIV_02 & & 0.687 & & \\
\hline MOTIV_07 & & & 0.826 & \\
\hline MOTIV_06 & & & 0.815 & \\
\hline MOTIV_14 & & & & 0.838 \\
\hline MOTIV_15 & & & & 0.769 \\
\hline MOTIV_13 & & & & 0.467 \\
\hline
\end{tabular}

Source: own research.

the others. Social media interactions are also very important. The second factor of motivation is mainly about creating valuable content for themselves and for others, too. Here sharing the real experience is most important. The third factor is about influencing others in their choice. This is only about influencing, and it is independent from the value and the reality of the content. The fourth factor is about investment for actions in the future, for example, creating a content because it will be useful for others later, or the user can use it to win a competition.

Based on the factor analysis, a cluster analysis was also conducted. The two-step cluster analysis by SPSS as well as the scree plot suggested creating three clusters based on the motivation values. K-means clustering was used to create the three groups. Table 4 shows the average values for the 16 motivations in each of the clusters, and the percentage of the members of the groups in 
2017 and 2018 (the bold values show the highest values for each group). The ANOVA-test was also conducted for the average values of all the motivations, and there was a significant $(\mathrm{p}<0.01)$ difference for the three groups created by the k-means clustering.

Table 4

Average values for motivations for the three clusters

\begin{tabular}{l|c|c|c|c}
\hline Cluster name & $\begin{array}{c}\text { Creators of real value } \\
\text { for everyone (Group } \\
\text { A) }\end{array}$ & $\begin{array}{c}\text { Creators of value } \\
\text { for themselves } \\
\text { (Group B) }\end{array}$ & $\begin{array}{c}\text { Social media } \\
\text { celebrities } \\
\text { (Group C) }\end{array}$ & Total \\
\hline MOTIV_01 & $\mathbf{4 . 2 7}$ & 1.80 & $\mathbf{4 . 9 3}$ & 3.51 \\
\hline MOTIV_02 & $\mathbf{3 . 9 7}$ & 1.54 & $\mathbf{5 . 0 7}$ & 3.31 \\
\hline MOTIV_03 & $\mathbf{4 . 5 1}$ & 1.67 & $\mathbf{5 . 0 7}$ & 3.60 \\
\hline MOTIV_04 & 1.96 & 1.12 & $\mathbf{4 . 2 0}$ & 2.08 \\
\hline MOTIV_05 & $\mathbf{4 . 1 1}$ & 1.74 & $\mathbf{4 . 9 1}$ & 3.42 \\
\hline MOTIV_06 & $\mathbf{3 . 5 7}$ & 1.67 & $\mathbf{3 . 8 9}$ & 2.95 \\
\hline MOTIV_07 & 2.85 & 1.34 & $\mathbf{3 . 4 9}$ & 2.43 \\
\hline MOTIV_08 & $\mathbf{6 . 1 8}$ & $\mathbf{3 . 8 8}$ & $\mathbf{5 . 3 7}$ & 5.21 \\
\hline MOTIV_09 & 1.89 & 1.17 & $\mathbf{3 . 9 6}$ & 2.02 \\
\hline MOTIV_10 & 1.76 & 1.17 & $\mathbf{4 . 1 3}$ & 2.00 \\
\hline MOTIV_11 & 1.39 & 1.07 & $\mathbf{3 . 7 6}$ & 1.72 \\
\hline MOTIV_12 & 1.51 & 1.09 & $\mathbf{4 . 0 4}$ & 1.83 \\
\hline MOTIV_13 & 1.88 & 1.33 & 3.33 & 1.96 \\
\hline MOTIV_14 & 1.82 & 1.39 & 2.87 & 1.86 \\
\hline MOTIV_15 & 1.61 & 1.22 & 2.54 & 1.65 \\
\hline MOTIV_16 & 2.28 & 1.34 & $\mathbf{4 . 3 5}$ & 2.33 \\
\hline Percentage in 2018 & $39.8 \%$ & $43.2 \%$ & $16.9 \%$ & \\
\hline Percentage in 2017 & $58.6 \%$ & $18.2 \%$ & $23.2 \%$ & \\
\hline
\end{tabular}

Source: own research.

- "Social media celebrities" (Group C) are really important in sharing experiences. They are willing to generate content, even if they have to show not the reality but a better life. They made up around $20 \%$ of the whole sample. Based on their answers, they want to be the influencers, which means that a significant part of the sample tries to act this way.

- For generating important and valuable content, the authors suggest that one should trust the first cluster "Creators of real value for everyone" (Group A). They only had higher values for the motivations about helping others and creating real memories. These were the most important of the feedback 
loop of the ZMOT model. In the average of the two years they numbered around half of the users.

- A third group was also identified, which was almost half of the sample in 2018, namely "Creators of value for themselves" (Group B). According to the average values of the motivation, the only one that was higher than 2 (on a scale from 1 to 7) was creating memories for themselves to watch them later to help remember the experiences. They are not interested in sharing experience, helping others or being a celebrity, or getting social media interactions on their content.

Based on the results of k-means clustering and Table 4, hypothesis H1 is acceptable for the sample and can be used later on for research about festivals. Three groups of visitors can be found in the sample whose motivations are different in many ways, according to the explanations above.

Table 5 shows the average values for each factors in the different clusters. Social media celebrities (Group C) try to maximize the effects in all four factors, these have the higher average for all of them. Creators of real value for everyone (Group A) has a quite high average value for showing real experience and for influencing (it is almost as high as for the celebrities). For them, self-expression and investment are much less important. Creators of value for themselves (Group B) have a moderately high value only for the real experience factor which includes the motivation factor 8 , the only factor that had an average value over 2 for this group (3.88).

Table 5

Average values for the factors in the different clusters

\begin{tabular}{l|c|c|c}
\hline \multirow{2}{*}{ Factors } & \multicolumn{3}{|c}{ Clusters } \\
\cline { 2 - 4 } & $\begin{array}{c}\text { Creators of real } \\
\text { value for everyone } \\
\text { (Group A) }\end{array}$ & $\begin{array}{c}\text { Creators of value for } \\
\text { themselves (Group } \\
\text { B) }\end{array}$ & $\begin{array}{c}\text { Social media } \\
\text { celebrities } \\
\text { (Group C) }\end{array}$ \\
\hline $\begin{array}{l}\text { Self-expression on social } \\
\text { media }\end{array}$ & 1.796 & 1.161 & $\mathbf{4 . 0 7 1}$ \\
\hline $\begin{array}{l}\text { Real experience for myself } \\
\text { and others }\end{array}$ & $\mathbf{4 . 6 0 9}$ & $\mathbf{2 . 1 2 8}$ & $\mathbf{5 . 0 7 1}$ \\
\hline To influence others & $\mathbf{3 . 2 1 3}$ & 1.507 & $\mathbf{3 . 6 8 7}$ \\
\hline Investment for the future & 1.766 & 1.314 & $\mathbf{2 . 9 1 6}$ \\
\hline
\end{tabular}

Source: own research.

Based on other semantic scale questions, the third group is different in their willing to share their experiences, and comprises only $12 \%$ open to sharing their experience, while the creators of real value are only $38 \%$, and the celebrities have the highest (58\%) value. Based on the statements "I have 
several memorable experiences from the festivals" and "I am happy to remember and recall the memorable experiences of festivals" both the Social media celebrities (Group C) and the Creators of real content (Group A) had a higher value than the creators of content for themselves. For the second statement, Creators of real value (Group A) had $86 \%$ and celebrities $80 \%$. Based on the t-test for these groups, there is a significant difference between these percentages ( $p=0.013$, equal variances not assumed). This also means that although for both groups $A$ and $C$ remembering these things is important, recalling is more frequent and plays a slightly more significant role for the Real value creators (Group A). Celebrities (Group C) rather create value for others. The same can be interpreted from the average values of Table 4 in the case of MOTIV_8. Creators of real value (Group A) have also a higher average on creating value for themselves than in the case of the Celebrities (Group C).

To decide about hypothesis $\mathrm{H} 2$ based on Table 5, the "real experience for myself" factor is the most important one for all three groups. Self-expression is mainly important for the "Social media celebrities" group $(C)$. Based on this, $\mathrm{H} 2$ can be rejected for the sample. The same result can also be projected for further research: if the same three groups can be found in the sample, only for the "Social media celebrities" type would social media be significantly important.

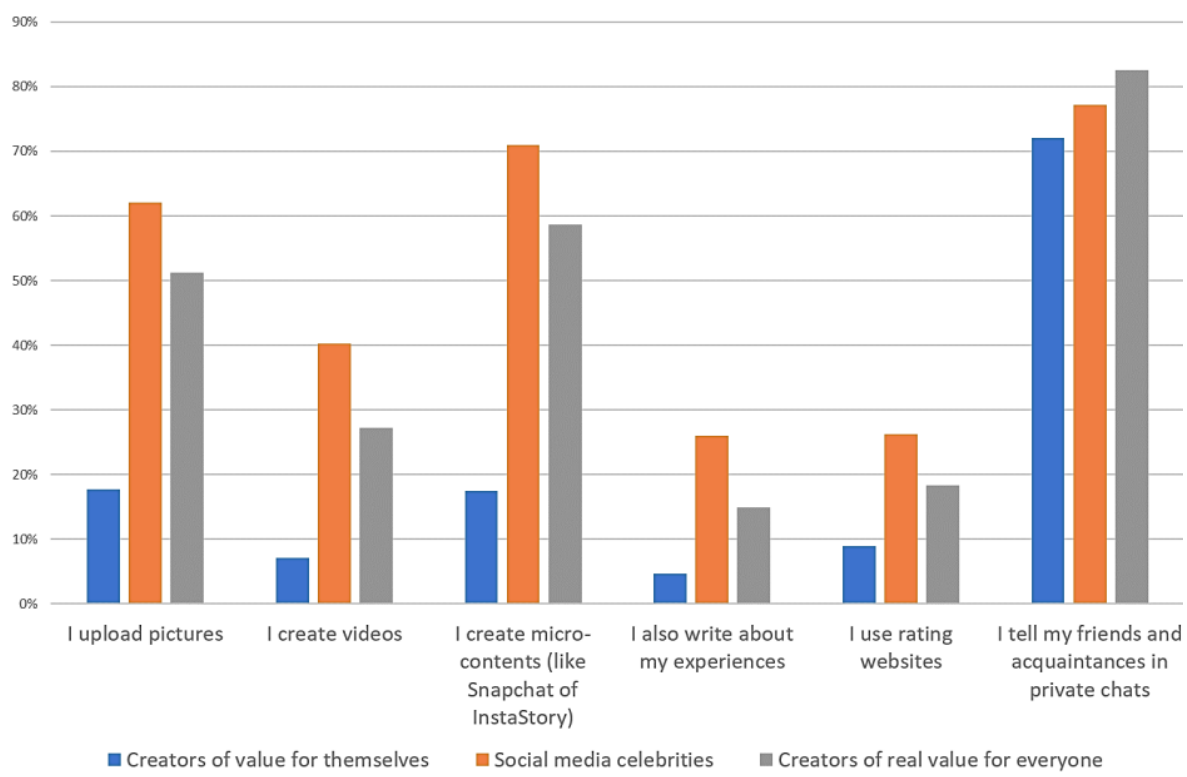

Fig. 2. Willingness to share experiences in different types of media for the clusters (\%) Source: own content. 
In the questionnaire for 2018, the type of content was also investigated. Figure 2 shows the average percentage value of the "willingness of sharing memories" for different types of content. Sharing experiences through private chats like Facebook Messenger, Instagram Direct Messages, WhatsApp, and Viber, is frequent for all three clusters, especially for the creators of valuable content. The authors suggest that this is because a one-to-one type customerto-customer communication creates more trust, is more intimate and more reliable. Sharing pictures and creating micro-content (content available only for a limited time and much less valuable) are also really popular, mainly for valuable experience. The importance of micro-content is a significant indication that sharing experience is usually not a previously planned action, as users usually do not prepare for it. This is rather the result of the "heat of the moment". Social media celebrities (Group C) have a higher percentage for all many-to-many communication categories of consumer-generated content.

\subsection{Gathering information from shared experiences}

To answer RQ2, based on Xiang et al. (2015), from 2016 collection of information sources were included to understand how Generation $\mathrm{Z}$ plans their travelling experiences and festival visits. Figure 3 shows the results for

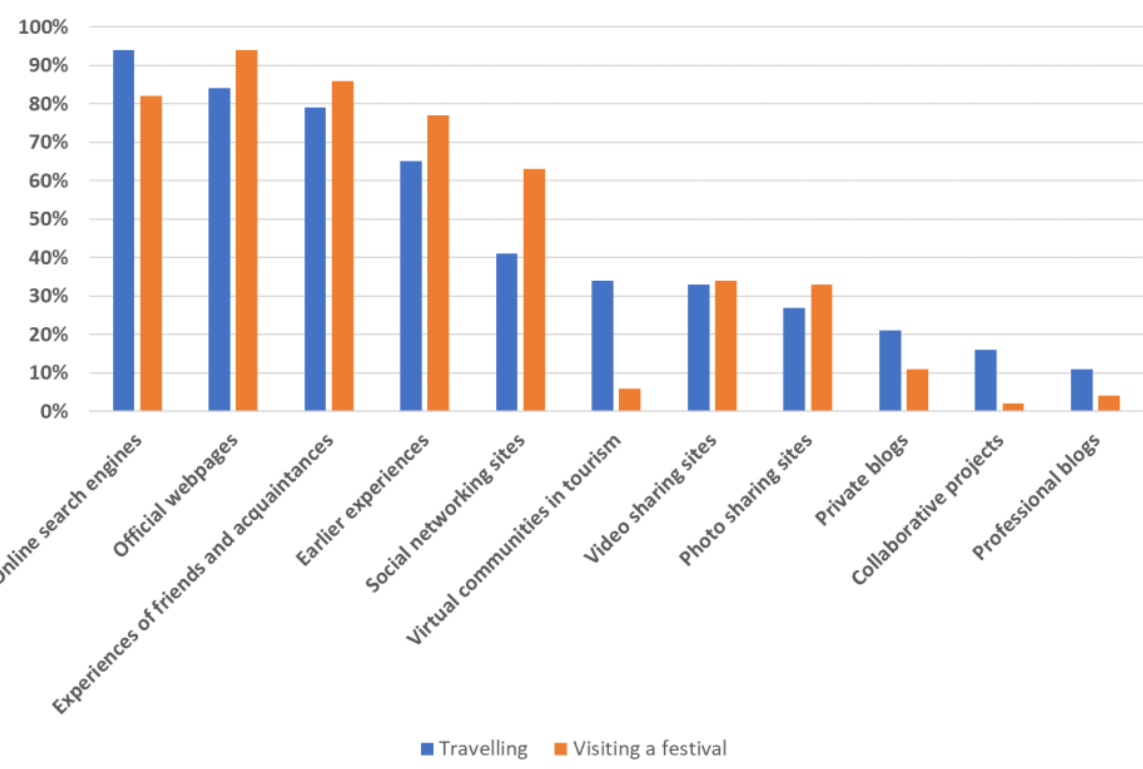

Fig. 3. Decision-making in the case of travelling and visiting a festival for the whole sample (in \%)

Source: own research. 
2018 for the most important factors and social media sources for travelling and visiting a festival. To create the social media categories and the information sources, the study used notations by Minazzi (2015), Xiang et al. (2015) and Choe et al. (2017). Photo and video sharing websites and apps were divided into two categories, because the effort required in sharing information and the depth of the content can be really different for a video and a photograph.

For tourism, the results by search engines, virtual communities (e.g. TripAdvisor) and collaborative projects (e.g. Wikipedia) are much more important than for visiting a festival (although it can be a tourist programme, too). For festivals, their own experiences and those of others are rather important, and social network sites have a significant role, too.

Compared to Xiang's (2015) results for Generation Z, video-sharing and photo-sharing and social networks play a rather influential role both in tourism and in festivals. This result is consistent with Süli and Martyin's (2017), who also emphasised the role of photo and video-sharing (especially the so-called 'aftermovies'), and their usefulness for younger generations.

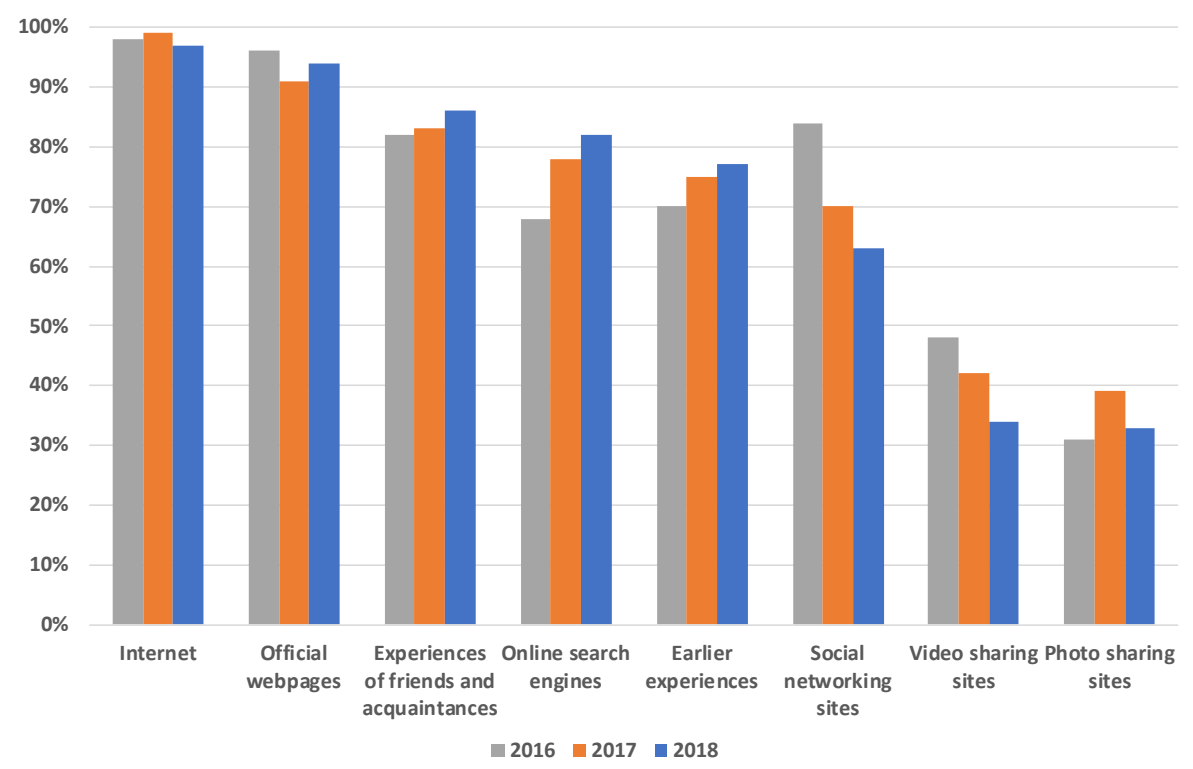

Fig. 4. Trends of the most important factors in information gathering for visiting a festival

Source: own research.

Analysing the trends of the last three years (see Figure 4), one can see that although these sources have a significant value for video-sharing and for social networks, yet it is decreasing. Xiang et al. (2015) showed a significant 
improvement in using photo and video sharing sites for travel-planning. Wang (et al., 2012) also emphasised this result. Their percentages were rather low even for 2012, compared to the results here. Their sample consisted mainly of members of older generations. It is clear that for younger generations these social media elements are fairly important, and according to Kang and Schuett (2013) their importance can be interpreted as the tourism experience and social media experience both created through sharing with others.

Based on the results in Figures 3 and 4, one can assume that social media elements and social interactions are more important regarding a festival visit than for planning a regular touristic trip, but their importance is rather decreasing. Thus hypothesis $\mathrm{H} 3$ cannot be accepted for the sample.

Based on the cluster analysis of experience sharing, it is also an important part of the ZMOT model to see what kind of sources they are using. Figure 5 shows the differences among the three clusters. For the usage and influencing effect of the depicted six sources a significant difference appeared among the three groups of users based on the Chi-square homogeneity test $(p<0.05)$.

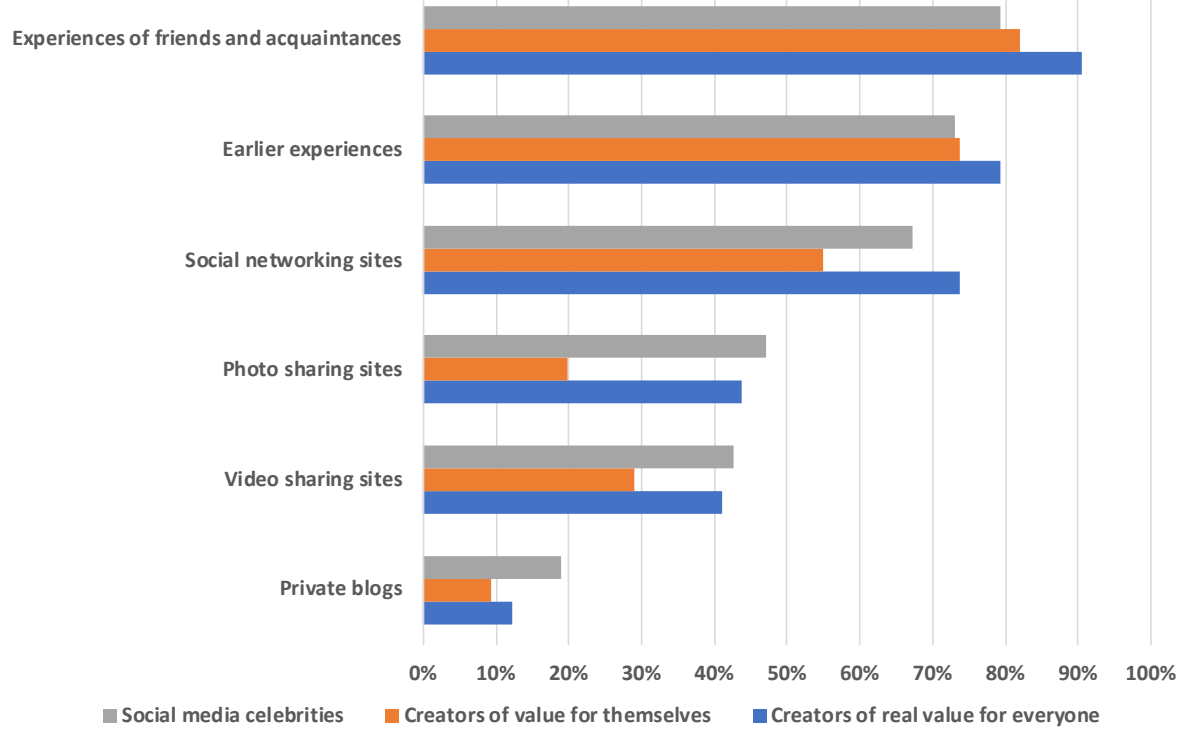

Fig. 5. Differences of usage of social and social media resources among the three groups

Source: own research.

One can see that "Creators of real value" (Group A) trust friends and acquaintances more than the other two groups' members, although they also pay a lot of attention to the experiences of other well-known persons. For 
them, their previous experiences are also a relevant factor. The authors suggest that they are aware of creating valuable content and can justify the experience in a better, more efficient way. Hence, they rather trust their own experiences, and they feel that they are a good and reliable source. Moreover, they also trust others, and social networks are for them valuable platforms to gather information from other like-minded people. Photo-sharing demonstrates the most noteworthy difference among the three groups, with a significantly low percentage for the group of "Creators of value for themselves" (Group B) comprising almost $50 \%$ of the sample in 2018. Looking back at the results of Figure 2, it is quite important to emphasise that sharing photos and microcontent (which are usually photos available for a shorter period of time) was the most relevant action, besides private chatting, for this group (Group B).

Based on these results one can see that there is a difference and a gap between the content that users are willing to share, and that they rather want to see as information gathering.

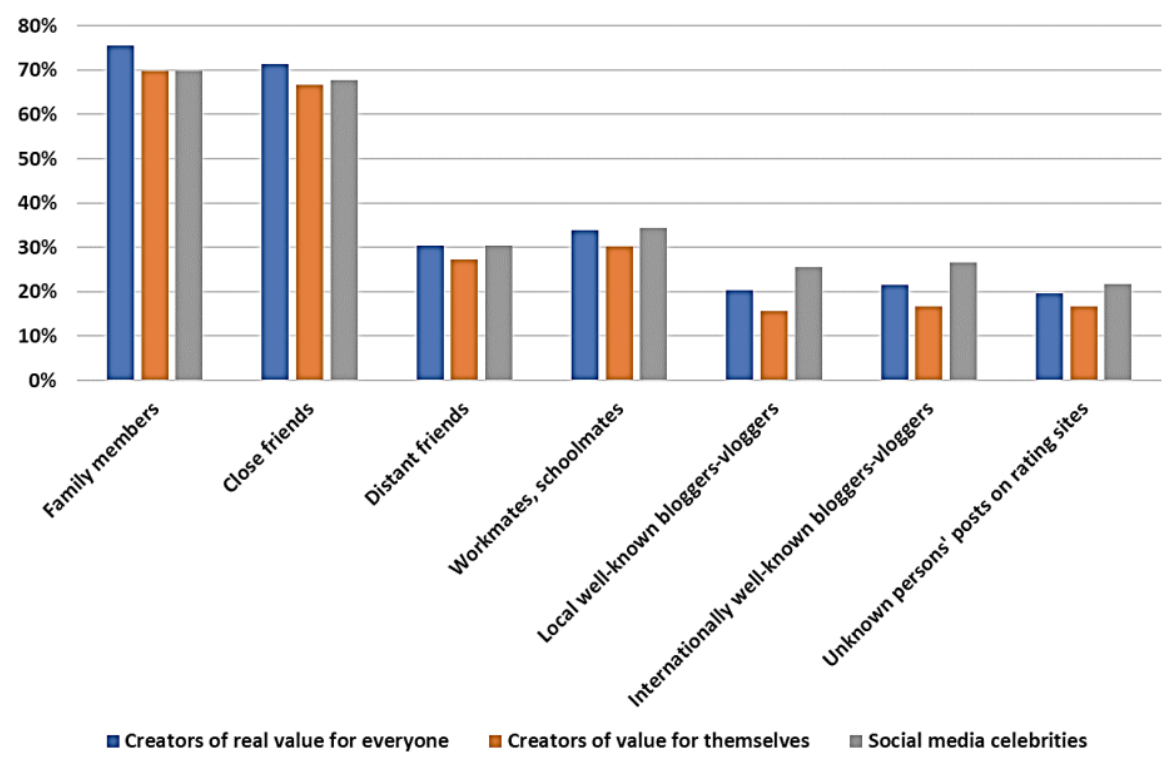

Fig. 6. Importance of different persons in travel decisions for the three groups

Source: own research.

The survey also dealt with the importance of some people in the decision progress. From Xiang's et al. (2015) research, it should be highlighted that "experiences of friends and acquaintances" constitute an important factor. The 
results also show that this factor is significant for all three groups (see Figure 5), and its importance has been increasing during the last few years (see Figure 4). Figure 6 shows how different types of friends, acquaintances and other persons have an effect on the decision process. Here also the results are divided into the three groups based on the motivations. One can see significant differences for local and international well-known bloggers $(\mathrm{p}<0.001)$ for the proportions. For these two categories, "Social media celebrities" (Group C) have the highest values, which can be interpreted that they would like to be influencers themselves and are more likely to appreciate other influencers. There was also a significant difference for family members and close friends $(\mathrm{p}<0.05)$, for which "Creators of real value" (Group A) had higher percentages. This can be interpreted that they try to create real value that people can trust, and they also try to trust and pay attention to persons that they know from real life and whom they trust.

Based on the results explained above and shown in Figures 5 and 6, one can assume that the three identified groups present significant differences regarding the importance of different online social media sources and different persons. Based on this, hypothesis $\mathrm{H} 4$ can be accepted for the sample.

\section{CONCLUSIONS, LIMITATIONS AND FURTHER SUGGESTIONS}

Although numerous studies deal with the importance of social media in tourism, there is a limited number of papers concerning events and festivals. Based on the results detailed in the previous section, some important managerial implications can be formed from the sample which included typical visitors of the above-mentioned Hungarian festivals. Although there are some limitations because of the sampling method, these results cannot be generalized for all the festival visitors in Hungary, but as part of the exploratory research the hypotheses tested with this size of the sample suggest some results that can be compared with the literature, and be used for further research. Additionally, based on the detailed results, the same questionnaire and hypotheses can also be used with probability sampling methods for the visitors of festivals, therefore the results could be more generalized.

From the results, three important groups of social media users can be created in the sample. Based on the sample size and the size of the groups, all of them can play an important role for marketers.

- The goal of marketers is to have reliable user-generated content because the sources of this type of content are relevant for the users generally in the information gathering phase. There is a great number of visitors who are willing to create valuable content for other persons too (Group A). 
Reaching them with a successful marketing campaign, suggesting to them to create more valuable content, and rewarding them for creating this content, should be a vital part of a marketing strategy.

- There is also a significant number of visitors who are not open yet to share memories online with others, the ones who only try to create memories for themselves (Group B). Although they create memories, they should be convinced to share their memories with others too because it is an important source for decision making, so they can help other persons. According to the results they are also less open to reaching for other persons shared experiences, or rather they are not aware of the potential benefits of sharing and searching for shared content. With the right communication they could be convinced that this feedback loop helps them, so they can be transformed to the other previously described group.

- The most problematic group could be the users who would like to be influencers (Group C). They are rather interested in creating a glossy online image and make other people jealous. For them, social presence is much important than showing valuable content. For marketers it can be suggested to convince them through an effective communication campaign that they can be important influencers if they show real value for others and they pay attention to the actual real experience. Thus they can also be transformed to members of the group called "creators of real value".

Besides the limitations of the sampling method, there are also some limitations to this study because of the structure of the questionnaire. Firstly, it is limited to music and cultural festivals in Hungary, so the findings cannot simply be generalized to other events like gastronomy or classical music festivals. Further studies should be conducted on different types of events and these results should be compared. Secondly, this study focuses on Generation $\mathrm{Z}$ (the target market of Hungarian music festivals), so further studies should pay more attention to other generations, and those results should be also compared. Finally, this study only investigated motivational factors and information sources for decision planning.

Further research could investigate the decision factors of a festival, satisfaction and the effects on motivations and sharing behaviour. As seen from the results, there were also significant differences in the sharing of the different types of media (photos, videos, micro-content) for the sample. The importance of these types in the information gathering phase can vary. This disparity should also be investigated in the near future to help marketers with creating campaigns and communication with different groups. To create successful marketing campaigns in this area of services, the connections with the 7P model and other relevant models should also be investigated. Table 6 
Table 6

Average values for the factors regarding the different clusters

\begin{tabular}{|c|c|c|c|}
\hline \multirow[b]{2}{*}{ Topics } & \multicolumn{3}{|c|}{ Clusters } \\
\hline & $\begin{array}{c}\text { Creators of real } \\
\text { value for everyone } \\
\text { (Group A) }\end{array}$ & $\begin{array}{l}\text { Creators of value for } \\
\text { themselves (Group B) }\end{array}$ & $\begin{array}{c}\text { Social media } \\
\text { celebrities } \\
\text { (Group C) }\end{array}$ \\
\hline $\begin{array}{l}\text { Usage of social } \\
\text { media in the } \\
\text { information search } \\
\text { phase }\end{array}$ & $\begin{array}{l}\text { Social network } \\
\text { sites, earlier } \\
\text { experiences and } \\
\text { friends experiences } \\
\text { are important }\end{array}$ & $\begin{array}{l}\text { Earlier experiences } \\
\text { and friends' } \\
\text { experiences are } \\
\text { important }\end{array}$ & $\begin{array}{l}\text { Friends and earlier } \\
\text { experiences are not so } \\
\text { important }\end{array}$ \\
\hline $\begin{array}{l}\text { Importance } \\
\text { of different types } \\
\text { of persons }\end{array}$ & $\begin{array}{l}\text { Family member } \\
\text { and close friends } \\
\text { are rather } \\
\text { important for them }\end{array}$ & - & $\begin{array}{l}\text { Well-known bloggers/ } \\
\text { vloggers are more } \\
\text { important for them }\end{array}$ \\
\hline $\begin{array}{l}\text { Motivations } \\
\text { for sharing } \\
\text { experience }\end{array}$ & $\begin{array}{l}\text { Creating memories, } \\
\text { reviews and } \\
\text { influencing are } \\
\text { important for them }\end{array}$ & $\begin{array}{l}\text { Creating memories } \\
\text { are the only important } \\
\text { thing }\end{array}$ & $\begin{array}{l}\text { All factors were } \\
\text { important for them }\end{array}$ \\
\hline $\begin{array}{l}\text { Different types } \\
\text { of media for sharing } \\
\text { experience }\end{array}$ & $\begin{array}{l}\text { Average values } \\
\text { almost reach the } \\
\text { values for Group C }\end{array}$ & $\begin{array}{l}\text { Only private conversa- } \\
\text { tions have a significant } \\
\text { average value }\end{array}$ & $\begin{array}{l}\text { The highest average } \\
\text { for media reaching } \\
\text { masses }\end{array}$ \\
\hline
\end{tabular}

Source: own research.

shows the three clusters and the topics discussed in the results of the exploratory research, and suggests the topics for using the four hypotheses and any further hypothesizes in future research.

\section{REFERENCES}

Akgunduz, Y., Coşar, Y., Motivations of event tourism participants and behavioural intentions, Tourism and Hospitality Management, Vol. 24(2), 2018.

Campos, A. C., Mendes, J., do Valle, P. O., Scott, N., Co-Creation Experiences: Attention and Memorability, Journal of Travel \& Tourism Marketing, Vo. 33(9), pp. 1309-1336, 2016.

Choe, Y., Kim, J., Fesenmaier, D. R., Use of social media across the trip experience: An application of latent transition analysis, Journal of Travel \& Tourism Marketing, Vol. 34(4), pp. 431-443, 2017.

Coelho, M. de F., Gosling, M. de S., Almeida, A. S. A. de., Tourism experiences: Core processes of memorable trips, Journal of Hospitality and Tourism Management, Vol. 37, pp. 11-22, 2018.

Deli-Gray, Zs., A Sziget [The Sziget Festival] [in:] Deli-Gray, Zs., Árva, L. (eds.), Turizmusmarketing esettanulmányok [Tourism marketing case studies], pp. 129-137. Akadémiai Kiadó, Budapest, 2010. 
Deng, N., Liu, J., Dai, Y., Li, H., Different cultures, different photos: A comparison of Shanghai's pictorial destination image between East and West, Tourism Management Perspectives, Vol. 30, pp. 182-192, 2019.

Getz, D., Event tourism: Definition, evolution, and research, Tourism Management, Vol. 29(3), pp. 403-428, 2008.

Gretzel, U., Yoo, K. H., Use and Impact of Online Travel Reviews [in:] O’Connor, P., Höpken, W., Gretzel, U. (eds.), Information and Communication Technologies in Tourism 2008. Springer, Vienna 2008.

Fazekas, I., Harsányi, D., Marketingkommunikáció érthetöen [Marketing communication understandably]. Szokratész Kiadó, Budapest 2011.

Hair, J. F., Black, W. C., Babin, B. J., Anderson, R. E., Multivariate data analysis, Seventh Edition. Pearson, Essex 2014.

Harsányi, D., Események és élmények [Events and experiences] [in:] Horváth, D., Bauer, A. (eds.), Marketingkommunikáció [Marketing communication]. Akadémiai Kiadó, Budapest 2013.

Hunyadi, Zs., Inkei, P., Szabó, J. Z., Fesztivál-Világ [Festival World], Kelet-Közép-Európai Kulturális Obszervatórium Alapítvány, Budapest 2006.

Husz, A., Turizmus, fesztiválok és helyi vonzerö [Tourism, festivals and local attraction] [in:] Aubert, A., Gyuricza L., Huszti Zs. (eds.), A kultúra turizmusa a turizmus kultúrája [The tourism of culture and the culture of tourism]. Publikon Kiadó, Pécs 2012.

Kang, M., Schuett, M. A., Determinants of Sharing Travel Experiences in Social Media, Journal of Travel \& Tourism Marketing, Vo. 30(1-2), pp. 93-107, 2013.

Kaplan, A. M., Haenlein, M., Users of the world, unite! The challenges and opportunities of Social Media, Business Horizons, Vol. 53(1), pp. 59-68. 2010.

Kelemen-Erdős, A., Mitev, A. Z., Eszképizmustól az ajánlásig - Élményfokozatok és hatásai a romkocsmákban [From escapism to recommendations - Degrees of experience and their effect in the case of ruin bars], Turizmus Bulletin, Vol. 20(2), pp. 14-21, 2020.

Keller, K. L., Kotler, P., Marketingmenedzsment [Marketingmanagement], Akadémiai Kiadó, Budapest 2016.

Kim, H., Xiang, Z., Fesenmaier, D. R., Use of The Internet for Trip Planning: A Generational Analysis, Journal of Travel \& Tourism Marketing, Vol. 32(3), pp. 276-289, 2015.

Kim, J., Fesenmaier, D. R., Sharing Tourism Experiences, Journal of Travel Research, Vol. 56(1), pp. 28-40, 2016.

Kladou, S., Mavragani, E., Assessing destination image: An online marketing approach and the case of TripAdvisor, Journal of Destination Marketing \& Management, Vol. 4(3), pp. 187193, 2015.

Kovács, G., A Sziget Fesztivál turisztikai vonatkozásai [The touristic effect of Sziget Festival], Turizmus Bulletin, Vol. 13(1), pp. 28-33, 2009a.

Kovács, G., A Sziget Fesztivál és a Balaton Sound látogatói [The visitors of Sziget Festival and Balaton Sound], Turizmus Bulletin, Vol. 13(3), pp. 71-72, $2009 \mathrm{~b}$.

Kovács, I., Petruska I., The Operation of Innovation Clusters in Light of Relationships in Hungary - Qualitative Research Findings, Argumenta Oeconomica, Vol. 2(43), 2019.

Kundi, V., Rendezvények, fesztiválok hatása a városok fejlödésére [The effect of events, festivals on the development of the cities] [in:] Michalkó, G., Rátz T. (eds.), A turizmus dimenziói: 
humánum, ökonómikum, politikum [The dimensions of tourism, people, economics, politics]. Kodolányi János Főiskola, Székesfehérvár 2011.

Lecinski, J., Winning the Zero Moment of Truth, available at https://www.thinkwithgoogle.com/ research-studies/2011-winning-zmot-ebook.html, accessed at 01/06/2019, 2011.

Malhotra, N. K., Birks, D. F., Marketing research - An applied approach. Third European edition. Pearson Education, United Kingdom, 2007.

Malhotra, N. K., Nunan, D., Birks, D. F., Marketing research - An applied approach. Fifth edition. Pearson Education, United Kingdom, 2017.

Marine-Roig, E., Anton Clavé, S., Tourism analytics with massive user-generated content: the case study of Barcelona, Journal of Destination Marketing \& Management, Vol. 4(3), pp. 162-172, 2015.

Marine-Roig, E., Destination Image Analytics through Traveller-Generated Content, Sustainability, Vol. 11(12), pp. 1-23, 2019.

Mehmetoglu, M., Engen, M., Pine and Gilmore's Concept of Experience Economy and Its Dimensions: An Empirical Examination in Tourism, Journal of Quality Assurance in Hospitality and Tourism, Vol. 12(4), pp. 237-255, 2011.

Minazzi, R., Social Media Marketing in Tourism and Hospitality. Springer International Publishing, London 2015.

Mitev, A., Irimiás, A., Michalkó, G., Franch, M., "Mind the scenery!” Landscape depiction and the travel intentions of Game of Thrones fans: some insights for DMOs, Regional Statistics, Vol. 7(2), pp. 58-74, 2017.

Morgan, M., What makes a Good Festival? Understanding the Event Experience, Event Management, 12(2), Vol. pp.81-93, 2008.

Munar, A. M., Jacobsen, J. K. S., Motivations for sharing tourism experiences through social media, Tourism Management, Vol. 43, pp. 46-54, 2014.

Nemec Rudež, H., Vodeb, K., Students' use of social media during the travel process, Tourism and Hospitality Management, Vol. 21(2), pp. 179-190, 2015.

Nowacki, M., Niezgoda, A., Identifying the destination image and its attributes: the case of Central and Eastern European cities, Prace Naukowe Uniwersytetu Ekonomicznego we Wrocławiu, Vol. 63(8), pp.118-127, 2019.

O’Sullivan, D., Jackson, M. J., Festival Tourism: A Contributor to Sustainable Local Economic Development?, Journal of Sustainable Tourism, Vol. 10(4), pp. 325-342, 2002.

Rivera, M., Semrad, K., Croes, R., The five E's in festival experience in the context of Gen $Y$ : Evidence from a small island destination, Revista Española de Investigación de Marketing ESIC, Vol. 19(2), pp. 95-106, 2015.

Rátz, T., A kultúra élménye, az élmény kultúrálja - A fesztiválok szerepe a kulturális turizmusban [The experience of culture, the culture of experience - The role of the festivals in the case of cultural turism], [in:] Aubert, A., Gyuricza L., Huszti, Zs. (eds.), A kultúra turizmusa a turizmus kultúrája [The tourism of culture and the culture of tourism]. Publikon Kiadó, Pécs 2012.

Sajtos, L., Mitev, A., SPSS Kutatási és adatelemzési kézikönyv [Handbook of research and data analysis with SPSS]. Alinea Kiadó, Budapest 2007.

Sedera, D., Lokuge, S., Atapattu, M., Gretzel, U., Likes - The key to my happiness: The moderating effect of social influence on travel experience, Information \& Management, Vol. 54(6), pp. 825-836, 2017. 
Semrad, K., Rivera, M., Advancing the 5E's in festival experience for the Gen Y framework in the context of eWOM, Journal of Destination Marketing \& Management, Vol. 7, pp. 58-67, 2018.

Sija, M., Schauermann, P., A 15-25 éves fiatalok fesztivállátogatási szokásai [The festival visiting habits of young people between 15 and 25 years], Turizmus Bulletin, Vol. 13(3), pp. 28-30, 2009.

Soldić F., D., Shifts in tourists' attitudes towards the destination offering, Tourism and Hospitality Management, Vol. 24(2), 2018.

Süli, D., Martyin, Z., A közösségi média szerepe a fesztiválturizmusban - a Szegedi Ifjúsági Napok és a Green Future példáján [The role of social media concerning festival tourismThe case study of Youth Days in Szeged and Green Future festivals], Turizmus Bulletin, Vol. 17(3-4), pp. 24-32, 2017.

Taneja, H., Webster, J. G., Malthouse, E. C., Ksiazek, T. B., Media consumption across platforms: Identifying user-defined repertoires, New Media \& Society, Vol. 14(6), pp. 951-968, 2012.

Tussyadiah, I. P., The Influence of Innovativeness on On-Site Smartphone Use Among American Travelers: Implications for Context-Based Push Marketing, Journal of Travel \& Tourism Marketing, Vol. 33(6), pp. 806-823, 2015.

Wang, Y., Fesenmaier, D. R., Modeling Participation in an Online Travel Community, Journal of Travel Research, Vol. 42(3), pp.261-270, 2004.

Wang, D., Xiang, Z., Fesenmaier, D. R., Smartphone Use in Everyday Life and Travel, Journal of Travel Research, 55(1), pp. 52-63, 2014.

Xiang, Z., Gretzel, U., The role of social media in online travel information search, Tourism Management, Vol. 31(2), pp.179-188, 2010.

Xiang, Z., Wang, D., O’Leary, J. T., Fesenmaier, D. R., Adapting to the Internet, Journal of Travel Research, Vol. 54(4), pp. 511-527, 2014.

Zavodna, L. S., Zavodny Pospisil, J., Social media use among Czech university students during the travel process, Tourism and Hospitality Management, Vol. 24(1), pp. 1-15, 2018.

Received: August 2019, revised: August 2020 